\title{
PENGEMBANGAN MODUL MATEMATIKA BERBASIS BUDAYA MANDAILING DENGAN PENDEKATAN MATEMATIKA REALISTIK (PMR) UNTUK MENINGKATKAN KEMAMPUAN KOMUNIKASI MATEMATIK
}

Oleh:

\author{
Ade Rahman Matondang \\ PGRA, Fakultas Agama Islam, Universitas Al Washliyah Medan \\ E-mail: adematondang55@gmail.com
}

doi : 10.3082/axiom.v\%vi\%i.7230

\begin{abstract}
Abstrak:
Penelitian ini dimaksudkan untuk menggambarkan peningkatan keterampilan komunikasi matematis siswa dengan modul matematika berbasis budaya Mandailing dengan Pendekatan Matematika Realistik (PMR). Penelitian ini menggunakan model 4-D yang terdiri dari empat tahap: mendefinisikan, merancang, mengembangkan dan menyebarluaskan. Subjek penelitian ini adalah siswa kelas XI SMA 1 Batang Angkola. Data penelitian diperoleh dari lembar soal tes kemampuan komunikasi matematis. Hasil tes I dan tes II menunjukkan bahwa: (1) peningkatan keterampilan komunikasi matematis siswa dalam tes I adalah 79,23 naik menjadi 84,60 pada tes II. (2) Modul matematika berbasis budaya Mandailing yang dikembangkan telah dinyatakan valid baik dari segi konten dan konstruk; modul matematika berbasis budaya Mandailing yang dikembangkan dinyatakan mudah digunakan dilihat dari tanggapan siswa dan guru; dan modul matematika berbasis budaya Mandailing yang dikembangkan dinyatakan efektif dilihat dari kemampuan komunikasi matematis siswa.
\end{abstract}

\section{Kata Kunci:}

Komunikasi Matematika, Budaya, Modul

\begin{abstract}
:
This research is intended to describe the Enhancement of students' mathematical communication skills with Mandailing culture with Mathematics Realistic Approach based mathematics modules. This research uses a 4-D model which consists of four stages: defining, designing, developing and disseminating. The subjects of this study were students of class XI of Batang Angkola 1 High School. The research data were obtained from a mathematical communication ability test question sheet. The results of the test I and test II showed that: (1) the improvement of students' mathematical communication skills in the first test was 79.23, rising to 84.60 on the second test. (2) Mandailing culture-based mathematics modules developed is valid both in terms of content and construct; Mandailing culture based mathematics modules developed was easily used based on by students' dan teacher's response; and Mandailing culture based mathematics modules developed is effective, seen by student's mathematical communication skills.
\end{abstract}

Keywords:

Mathematical Communication, Culture, Module 


\section{A. Pendahuluan}

Pendidikan menjadi hal yang sangat penting sebagai modal untuk menjaga stabilitas bangsa. Dengan pendidikan yang baik, maka warga negara akan menciptakan suasana yang terdidik. Pendidikan memberi sumbangan besar dalam kemajuan suatu bangsa. Dalam prosesnya pendidikan bisa berinovasi sesuai tuntutan zaman. Pembelajaran yang dahulu hanya diperoleh di dalam kelas saat ini sudah mulai merambah ke dunia digital. Adanya penyedia jasa pembelajaran berbasis digital cenderung memudahkan proses belajar namun dengan adanya media ini, siswa sering kehilangan identitas budaya daerahnya.

Pentingnya budaya sebagai warisan leluhur adalah untuk menjaga kelestariannya di zaman ilmu pengetahuan yang semakin pesat. Pendidikan penting sebagai modal masa depan namun meninggalkan budaya juga berbahaya sebab akan menjauhkan generasi muda dari nilainilai luhur daerahnya. Kondisi ini menjadi perhatian penulis sehingga tertarik untuk mengembangkan modul matematika berbasis budaya mandailing.

Matematika menjadi salah satu primadona dalam dunia pendidikan. Hal ini bukanlah hal yang muluk, sejalan dengan pernyataan Cornelius (dalam Abdurrahman, 2009: 33) bahwa paling tidak matematika dapat membuat pembelajarnya berpikir jernih dan logis, memecahkan masalah, menumbuhkan kreativitas, menganalisis dan kesadaran pengembangan budaya. Dengan melatih kemampuan matematika siswa dapat diasumsikan siswa akan memiliki kemampuan-kemampuan dasar dalam kehidupan.

Paparan di atas menunjukkan betapa pentingnya matematika dikuasai oleh siswa. Salah satu kemampuan matematika yang sangat penting adalah kemampuan komunikasi matematik. Sejalan dengan NCTM (2000: 348) bahwa untuk grade 9-12 dikatakan "Changes in the workplace increasingly demand teamwork, collaboration, and communication. Similarly, college-level mathematics courses are increasingly emphasizing the ability to convey ideas clearly, both orally and in writing. To be prepared for the future, high school students must be able to exchange mathematical ideas effectively with others. However, there are more-immediate reasons for emphasizing mathematical communication in high school mathematics. Interacting with others offers opportunities for exchanging and reflecting on ideas; hence, communication is a fundamental element of mathematics learning. For that reason, it plays a central role in all the classroom episodes".

Selanjutnya Baroody (dalam Ansari 2009: 4) menyebutkan sedikitnya ada dua alasan penting mengapa komunikasi dalam matematika perlu ditumbuhkembangkan di kalangan siswa. Pertama, mathematics as language yaitu matematika menjadi alat komunikasi yang saling dipahami. Kedua, mathematics learning as sosial activity, artinya sebagai bahan dalam interaksi sosial. Baik sebagai bahasa maupun interaksi sosial, komunikasi matematika menjadi bahan yang dapat dipakai dalam kegiatan pembelajaran antara guru dan siswa.

Paparan di atas menunjukkan bahwa banyak persoalan ataupun informasi disampaikan dengan bahasa matematika, misalnya menyajikan persoalan atau masalah ke dalam model matematika yang dapat berupa diagram, persamaan matematika, grafik, ataupun tabel. Mengkomunikasikan gagasan dengan bahasa matematika justru lebih praktis, sistematis, dan efisien. Begitu pentingnya bahasa matematika sebagai komunikasi sehingga bahasa matematika merupakan bagian dari bahasa yang digunakan dalam masyarakat.

Selanjutnya kemampuan komunikasi matematik dapat diukur menggunakan intrumen yang disusun berdasarkan indikator komunikasi matematik. Dari soal-soal komunikasi matematik yang telah teruji kevalidannya diberikan kepada siswa kelas XI siswa SMA 1 Batang Angkola diperoleh informasi bahwa siswa kesulitan menjawab soal komunikasi pada indicator tertentu. Hal ini menandakan ada masalah dalam kemampuan komunikasi matematiksiswa. Jika kondisi ini terus dibiarkan, dikhawatirkan kemampuan komunikasi matematik siswa tidak terasah dan pada akhirnya tidak berkembang.

Untuk memperoleh infomasi lebih lanjut, maka dilakukan wawancara terhadap guru matematika di SMA Negeri 1 Batang Angkola di lokasi sekolah, terungkap fakta bahwa ada 
Ade Rahman Matondang: Pengembangan Modul Matematika Berbasis Budaya Mandailing dengan Pendekatan Matematika Realistik (PMR) untuk Meningkatkan Kemampuan Komunikasi Matematik

beberapa permasalahan yang dijumpai dalam pembelajaran matematika, diantaranya: siswa cenderung pasif dalam pembelajaran, siswa kurang merespon pertanyaan guru saat pembelajaran matematika, pembelajaran belum diarahkan untuk membangun pengetahuan dalam diri siswa, siswa cenderung menghindari matematika dan siswa tidak tertarik menjawab soal-soal matematika. Siswa tampak tidak mampu mengkomunikasikan apa yang ada di dalam pikirannya di depan kelas pada saat guru menanyakan pendapat siswa tersebut mengenai suatu permasalahan matematika.

Menurut Kilpatrick (2002: 25) untuk mencapai tujuan utama dalam proses pembelajaran matematika, perlu dilakukan perubahan beberapa komponen dari pendidikan matematika di sekolah. Khususnya tentang perangkat pembelajaran, bahan pembelajaran, penilaian, pendidikan guru dan pengembangan profesi serta memasyarakatkan sistem pendidikan yang dilakukan bersama-sama untuk menjamin keikutsertaan seluruh siswa dalam belajar matematika dari pendidikan dasar dan pendidikan menengah. Sehingga dapat disimpulkan untuk meningkatkan kualitas pembelajaran, maka perlu dikembangkan suatu modul pembelajaran yang mendukung kemampuan tersebut.

Modul pembelajaran yang baik haruslah benar, dapat dipakai dan efektif. Disimpulkan dari Akker (1999: 10) bahwa kriteria kualitas perangkat atau modul yang dikembangkan adalah kevalidan (validity), kepraktisan (practically), dan keefektifan (effectiveness). Sehingga dapat dinyatakan bahwa modul yang berkualitas adalah yang memenuhi ketiga aspek tersebut. Selanjutnya dari pernyataan Tati, dkk. (2009: 78) disimpulkan bahwa validitas diperoleh dari validasi modul oleh pakar (expert judgement) dan teman sejawat berisikan validasi isi (content), konstruk dan bahasa. Selanjutnya kepraktisan berarti bahwa modul pembelajaran dapat diterapkan oleh guru sesuai dengan yang direncanakan dan mudah dipahami oleh siswa. Sedangkan keefektifan dilihat dari hasil penilaian autentik yang meliputi penilaian terhadap proses pembelajaran dan hasil belajar.

Dalam penelitian ini modul yang dikembangkan adalah modul matematika berbasis budaya Mandailing dengan materi statistika. Materi statistika dipilih sebab ditemukan masalah berupa rendahnya nilai matematika siswa pada materi tersebut. Sedangkan integrasi budaya lokal (Budaya Mandailing) terhadap pembelajaran matematika diharapkan lebih mendorong rasa kedekatan siswa dengan materi pelajaran. Rasa ketertarikan pada konteks budaya Mandailing memacu siswa lebih aktif dalam mengkomunikasikan gagasannya serta siswa juga belajar mencintai serta menghargai budaya tanah air.

\section{B. Kajian Teoritis}

\section{Komunikasi Matematik}

Menurut Suriansyah (2014: 359) komunikasi adalah aktivitas yang selalu dilakukan oleh semua orang karena merupakan kebutuhan berinteraksi sosial. Selanjutnya Greenes \& Schulman (dalam Ansari, 2012: 12) menjelaskan komunikasi matematik adalah: kemampuan (1) menyatakan ide matematika melalui ucapan, tulisan, demonstrasi, dan melukiskannya secara visual dalam tipe yang berbeda, (2) memahami, menafsirkan, dan menilai ide yang disajikan dalam tulisan, lisan, atau dalam bentuk visual, (3) mengkonstruk, menafsirkan dan menghubungkan bermacam-macam representasi ide dan hubungannya. Dari pendapat ahli di atas, dapat disimpulkan bahwa komunikasi adalah proses atau cara penyampaian ide-ide, pandangan, pemikiran atau menjelaskan pengertian antar sesama pribadi yaitu komunikator dengan komunikan.

Kemampuan komunikasi matematik dalam penelitian ini adalah kemampuan siswa dalam menghubungkan benda nyata, gambar, dan diagram ke dalam ide matematika, menjelaskan ide, situasi dan relasi matematik baik secara lisan maupun tulisan dalam bentuk gambar atau grafik; menjelaskan serta membuat pertanyaan tentang matematika yang dipelajari dari suatu situasi yang diberikan. Adapun indikator yang menunjukan kemampuan komunikasi matematik dalam penelitian ini adalah: (1) Menuliskan ide matematika dalam gambar, (2) Menghubungkan 
gambar ke dalam ide matematika atau sebaliknya, dan (3) Menuliskan ide matematika ke dalam model matematika dan menyelesaikan masalah.

\section{Pendekatan Matematika Realistik}

Pendekatan Matematika Realistik (PMR) bermula dari pemberian masalah yang real bagi siswa. Masalah yang siswa temukan dalam kehidupan sehari-hari atau dengan kata lain masalah kontekstual.Dengan masalah ini siswa harus memiliki peran aktif dalam kegiatan pembelajaran, sementara guru berperan sebagai fasilitator. Guru dan siswa memiliki peran yang berbeda. Siswa dapat mengekspresikan dan mengkomunikasikan ide satu sama lain dan guru akan membantu dan mendukung untuk membandingkan ide dan juga untuk membuat keputusan. Ide mana yang terbaik di antara yang lainnya. Dengan karakteristik seperti itu, pendekatan matematika realistis Indonesia memiliki prospek yang baik untuk diterapkan. Kelebihan pendekatan ini diantaranya pada struktur, empiris, atau mekanismenya. Sehingga diharapan PMR adalah jawaban untuk masalah pendekatan matematika di Indonesia.

Pendekataan matematika realistik adalah pendekatan pendidikan yang telah dikembangkan lebih dari 40 tahun dalam bidang sains dan matematika. Kegiatan dari unit untuk mengembangkan pemahaman siswa tentang logaritma digunakan untuk memberikan contoh prinsip desain PMR formalisasi progresif. Dimulai dari konteks yang menimbulkan penalaran informal siswa, serangkaian representasi dan pertanyaan kunci digunakan untuk membangun hubungan antara representasi matematika formal, pra-formal dan formal. PMR menawarkan lebih dari satu cara untuk mendukung transisi siswa dari yang konkret ke abstrak. Urutan pembelajaran PMR dipahami sebagai "jalur pembelajaran" di mana konteks masalah digunakan sebagai titik awal untuk memperoleh penalaran informal siswa. Artinya, konteksnya adalah sumber untuk matematika yang baru.

Penjelasan di atas menjelaskan bahwa PMR kompeten untuk meningkatkan pemahaman matematika, kemampuan komputasi, dan kemampuan komunikasi. Ada beberapa karakteristik PMR menurut Gravameijer (2010) seperti:

a. Penemuan terbimbing melalui proses matematika yang progresif

Guided discovery Ahmadi (2011) adalah kegiatan belajar yang melibatkan seluruh kemampuan berpikir siswa untuk menemukan dan menyelidiki sesuatu secara sistematis, kritis, logis, dan analitis. Dan akhirnya para siswa dapat merumuskan penemuan mereka dengan penuh percaya diri.

b. Menggunakan fenomena didaktik

Konsep fenomenom didaktis Suprijono (2009) adalah fenomenom/konsep yang membantu guru untuk mengasosiasikan antara teori situasi dunia nyata yang mendorong siswa untuk membangun asosiasi antara pengetahuan yang mereka miliki dan aplikasi dalam kehidupan nyata mereka sebagai anggota keluarga atau anggota masyarakat

Papakadis, Kalogiannakis, \& Zaranis (2017) menyatakan bahwa "Holistically, our results suggest that teaching of realistic mathematics is a didactic approach with a positive effect, on the development of mathematical competence in kindergarten". Noviani, Syahputra, \& Murad (2017) menyatakan bahwa "improving students' spatial skills taught with Realistic Mathematics Education is better than conventional learning". Dari beberapa pendapat ahli di atas disimpulkan bahwa pengembangan modul matematika berbasis budaya Mandailing dengan PMR untuk meningkatkan kemampuan komunikasi komunikasi bukanlah suatu hal yang mustahil untuk dilakukan.

\section{Budaya Mandailing}

Di dalam situs Pemerintah Kabupaten Mandailing Natal Provinsi Sumatera Utara (https://madina.go.id/sejarah-dan-budaya-mandailing-natal/) dipaparkan sejarah dan budaya Mandailing. Pada tahun 1365, Mpu Prapanca, sejarawan Majapahit, menulis satu karya sejarah yang secara gamblang menyebutkan keberadaan Mandailing sebagai bagian yang penting di nusantara. Karya sejarah itu adalah Negarakertagama. Ungkapan dalam bahasa Mandailing 
"natarida" yang artinya yang tampak (dari kaki Gunung-gunung Sorik Marapi di Mandailing). Ungkapan ini kemudian berubah menjadi Natar. Sampai kini masih banyak orang Mandailing menyebut Natar untuk Natal, termasuk Batang Natar untuk Batang Natal.

Kabupaten Mandailing Natal diresmikan oleh Menteri Dalam Negeri pada tanggal 9 Maret 1999 dikantor Gubernur Sumatera Utara, Medan. Dalam rangka mensosialisasikan Kabupaten Mandailing Natal, Bupati Mandailing Natal, Amru Daulay, SH menetapkan akronim nama Kabupaten Mandailing Natal sebagai Kabupaten Madina yang Madani dalam Surat tanggal 24 April 1999 Nomor 100/253.TU/1999.

Ketika diresmikan, Kabupaten Mandailing Natal baru memiliki 8 Kecamatan, 7 Kelurahan dan 266 Desa. Kemudian pada tahun 2002 dilakukan pemekaran menjadi 17 Kecamatan, 322 Desa, 7 Kelurahan dan 10 Unit Pemukiman Transmigrasi (UPT). Pada tahun 2007 dimekarkan lagi menjadi 22 Kecamatan berdasarkan Peraturan Daerah No. 10 Tahun 2007, Setelah keluarnya Peraturan Daerah No. 8 Tahun 2008 tentang pembentukan Desa, Perubahan nama desa dan penghapusan Kelurahan, dengan demikian Kabupaten Mandailing Natal sampai pada akhir tahun 2010 terdiri dari 23 Kecamatan, 27 Kelurahan dan 377 Desa dengan budaya yang beragam diantaranya:

a. Sistem kehidupan masyarakat Mandailing Natal menggunakan sistem Dalian Na Tolu (tiga tumpuan). Artinya, mereka terdiri dari kelompok kekerabatan Mora (kelompok kerabat pemberi anak dara), Kahanggi (kelompok kerabat yang satu marga) dan Anak Boru (kelompok kerabat penerima anak dara). Yang menjadi pimpinan kelompok tersebut biasanya adalah anggota keluarga dekat dari Raja yang menjadi kepala pemerintahan di Negeri atau Huta asal mereka.

b. Bagas Godang yang merupakan tempat bermusyawarah dan bermufakat dalam menyelesaikan permasalahan yang terjadi di masyarakat, disamping itu Bagas Godang juga merupakan simbol daerah Kabupaten Mandailing Natal.

c. Sopo Godang yaitu balai sidang adat dan pemerintahan kerajaan), atau disatu bangunan khusus terletak di dekat Bagas Godang (istana raja)

d. Halaman Bagas Godang dinamakan Alaman Bolak Silangse Utang (Halaman Luas Pelunas Hutang). Sesiapa yang mencari perlindungan dari ancaman yang membahayakan dirinya boleh mendapat keselamatan dalam halaman ini. Menurut adat Mandailing, pada saat orang yang sedang dalam bahaya memasuki halaman ini, ia dilindungi Raja, dan tidak boleh diganggu-gugat.

e. Gordang Sambilan yaitu alat musik tradisional yang terdiri dari sembilan buah gendang. Sedangkan bentuk kesenian lainnya adalah tarian "tor tor mandailing" dan pada daerah pesisir dikenal kesenian "badendang" dengan diiringi pencak silat.

f. Gordang Sambilan yaitu jenis alat musik pukul seperti Bedug. Terdiri dari Sembilan bedug yang mempunyai panjang dan diameter yang berbeda sehingga menghasilkan nada yang berbeda pula.

g. Lubuk larangan yaitu Sungai yang dilepaskan ikan untuk dipanen bersama. Misalnya sungai Batang Gadis yang disebut Lubuk Larangan dengan panjang kira-kira $1 \mathrm{~km}$. Biasanya dua kali dalam setahun terbuka bagi umum untuk menangkap ikan namun dalam bantuk yang terorganisir. Pada waktu lain dilarang keras untuk menangkap ikan disini. Seseorang yang ingin ikut ambil bagian dalam menangkap ikan harus mendaftarkan dirinya kepada sekretariat dan harus membayar uang pendaftaran

h. Legenda Sampuraga yaitu legenda anak yang durhaka pada orangtua berupa sumur air panas akibat dikutuk oleh ibunya.

\section{Metode Penelitian}

Metode penelitian adalah penelitian pengembangan terhadap modul matematika berbasis budaya Mandailing dengan PMR. Penelitian dilaksanakan pada tahun ajaran 2019/2020 di SMA Negeri 1 Batang Angkola. Sampel dalam penelitian ini adalah siswa kelas XI IPA-1 dan IPA-2. Pengembangan dilakukan melalui model 4-D oleh Thiagarajan, Semmel dan Semmel pada 
materi statistika. Modul matematika berbasis budaya Mandailing dengan PMR yang dikembangkan melalui empat langkah yang disebut 4D yaitu langkah pendefenisian (define) mencakup analisis tugas dan analisis konsep materi, langkah desain (design) mencakup penyusunan tes kemampuan komunikasi matematis serta pemilihan media berupa modul, langkah pengembangan (develop) mencakup mengembangkan semua instrumen penelitian serta menguji coba draft hingga memperoleh instrumen akhir, dan langkah penyebaran (disseminate) mencakup penggunaan instrumen akhir ke sekolah. Pengembangan modul yang dimaksud dapat dilihat dalam Gambar 1.

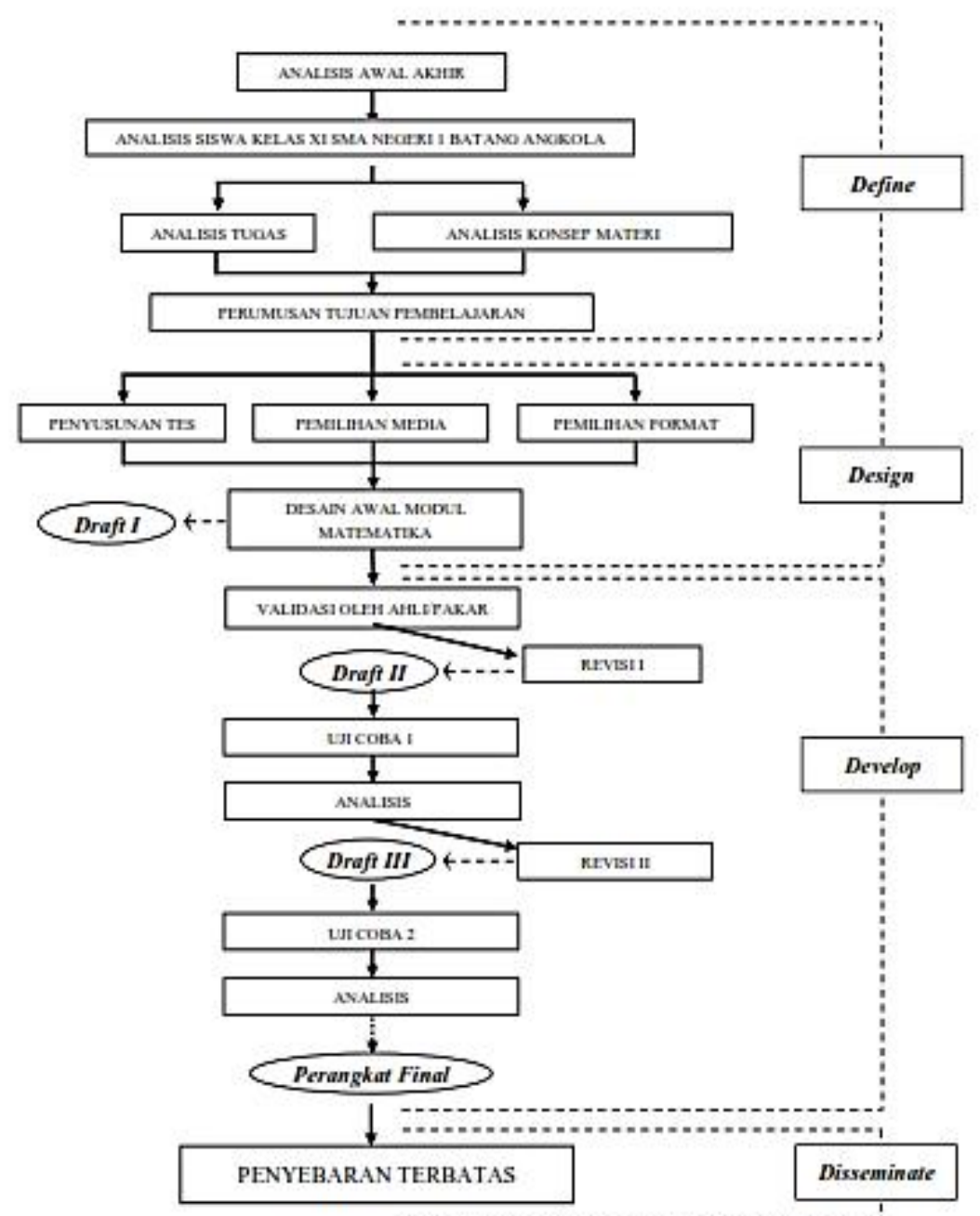

Gambar 1 . Modifikasi Bagan Pengembangan Modul Pembelajaran Model 4D (Thiagarajan 1974: 6-9)

\section{Hasil Penelitian dan Pembahasan}

Penelitian pengembangan ini dilakukan untuk memperoleh gambaran peningkatan kemampuan komunikasi matematik siswa kelas XI IPA SMA Negeri 1 Batang Angkola pada materi statistika. Perangkat yang dikembangkan berupa modul pembelajaran berbasis Budaya Mandailing. Modul yang baik jika telah memenuhi uji validitas, praktisitas, dan efektivitas. Uji validitas dan praktisitas merupakan dua uji yang wajib dipenuhi sehingga tidak disajikan lagi karena sudah dipastikan pemenuhannya.

\section{Peningkatan Kemampuan Komunikasi Matematik}

Data yang diperoleh dari hasil postes kemampuan komunikasi matematik siswa uji coba I dan II dianalisis untuk mengetahui peningkatan kemampuan komunikasi matematik siswa dengan membandingkan rata-rata skor siswa yang diperoleh siswa. Deskripsi peningkatan 
Ade Rahman Matondang: Pengembangan Modul Matematika Berbasis Budaya Mandailing dengan Pendekatan Matematika Realistik (PMR) untuk Meningkatkan Kemampuan Komunikasi Matematik

kemampuan komunikasi matematik siswa dengan menggunakan modul matematika berbasis budaya Mandailingdengan PMR pada uji coba I dan II disajikan pada Tabel 1.

Tabel 1. Deskripsi Hasil Kemampuan Komunikasi Matematik

\begin{tabular}{ccc}
\hline Keterangan & $\begin{array}{c}\text { Postes Kemampuan Komunikasi } \\
\text { matematik Uji Coba I }\end{array}$ & $\begin{array}{c}\text { Postes Kemampuan Komunikasi } \\
\text { matematik Uji Coba II }\end{array}$ \\
\hline Nilai Tertinggi & 92 & 97 \\
Nilai Terendah & 67 & 74 \\
\hline Rata-rata & 77,85 & 84,36 \\
\hline
\end{tabular}

Berdasarkan Tabel 1, hasil analisis peningkatan kemampuan komunikasi matematik siswa pada uji coba I dan II menunjukkan bahwa rata-rata kemampuan komunikasi matematik pada hasil postes uji coba I adalah sebesar 77,85 meningkat menjadi 84,36 pada uji coba II. Hal ini sesuai dengan analisis data peningkatan kemampuan komunikasi matematik, yaitu peningkatan komunikasi matematik dilihat dari rata-rata hasil postes uji coba I dan II. Dengan demikian, diketahui bahwa terdapat peningkatan rata-rata kemampuan komunikasi matematik siswa sebesar 6,51 poin. Berdasarkan analisis peningkatan ini dapat disimpulkan bahwa penggunaan modul matematika berbasis Budaya Mandailing dengan PMR dapat meningkatkan kemampuan komunikasi matematik siswa.

\section{Efektivitas Modul Matematika berbasis budaya Mandailing dengan PMR}

Hasil penelitian yang menunjukkan bahwa modul matematika berbasis budaya Mandailing dengan PMR yang dikembangkan telah memenuhi kriteria valid, praktis dan efektif. Validitas dilihat dari hasil validasi ahli yang terdiri dari 3 dosen UNIMED dan 2 guru matematika SMA. Aspek yang diperiksa validator mencakup format, isi dan bahasa pada modul matematika berbasis budaya Mandailingdengan PMR.

Hasil kepraktisan ujicoba I dan II menujukkan guru tertarik dan termotivasi dalam mengajar berdasarkan hasil wawancara dengan guru. Selanjutnya kepraktisan dari sudut pandang siswa menunjukkan bahwa lebih dari $80 \%$ siswa memberikan respon positif terhadap modul yang dikembangkan.

Hasil keefektifan ujicoba I dan II menunjukkan bahwa kriteria yang ditetapkan telah terpenuhi. Kriteria yang dimaksud adalah modul matematika berbasis budaya Mandailing dengan PMR efektif jika lebih dari $80 \%$ siswa telah memiliki kemampuan komunikasi matematik lebih dari $65 \%$. Pada ujicoba II terlihat bahwa rata-rata kemampuan siswa telah lebih dari $80 \%$.

\section{Pembahasan}

Berdasarkan hasil tes kemampuan komunikasi matematik pada uji coba I dan II, diperoleh hasil bahwa pada uji coba I yang dilakukan di kelas XI IPA-1 SMA Negeri 1 Batang Angkola diperoleh rata-rata kemampuan komunikasi matematik siswa sebesar 77,85 dengan persentase ketuntasan klasikal sebesar $79,23 \%$. Selanjutnya pada uji coba II di kelas XI IPA-2 SMA Negeri 1 Batang Angkola diperoleh rata-rata rata-rata kemampuan komunikasi matematik siswa sebesar 84,36 dengan persentase ketuntasan belajar klasikalnya sebesar 84,60\%.

Rata-rata kemampuan komunikasi matematik siswa dan persentase ketuntasan klasikal pada kedua uji coba menunjukkan bahwa penguasaan siswa terhadap kemampuan komunikasi matematik meningkat dari uji coba I ke uji coba II. Peningkatan rata-rata nilai siswa sebesar 6,51 poin dan peningkatan persentase ketuntasan belajar klasikal siswa sebesar 5,37\%. Hasil ini sesuai dengan penelitian Papakadis, Kalogiannakis, \& Zaranis (2017) juga menyimpulkan hasil penelitiannya bahwa secara umum mengajar dengan PMR memberikan efek positif dalam perkembangan kompetensi matematika anak usia dini. Penelitian di atas menunjukkan bahwa PMR mempengaruhi kemampuan kognitif siswa bahkan siswa yang dikenalkan matematika sejak usia dini. 
Selanjutnya penelitian Saleh, Prahmana, Isa \& Murni (2018) menyimpulkan bahwa prestasi dan peningkatan kemampuan penalaran siswa dengan menggunakan PMR lebih baik daripada pembelajaran konvensional. Hal ini senada dengan hasil penelitian Noviani, Syahputra, \& Murad (2017) yang menyatakan bahwa kemampuan spasial siswa dengan PMR lebih baik daripada pembelajaran biasa. Dari hasil penelitian di atas, tampak bahwa PMR memberikan sumbangan dalam meningkatkan kognitif siswa, dalam hal ini kemampuan komunikasi matematik.

\section{E. Simpulan}

Berdasarkan hasil analisis dan pembahasan dalam penelitian ini, dikemukakan beberapa simpulan yaitu bahwa peningkatan kemampuan komunikasi matematik uji coba I ke uji coba II sebesar 6,51 yaitu dari 77,85 menjadi 84,36. Selanjutnya validitas modul matematika berbasis budaya Mandailing dengan PMR dikembangkan telah memenuhi kiteria valid dilihat dari validasi oleh validator, kepraktisan modul dipenuhi dari respon siswa dan guru positif terhadap modul matematika berbasis budaya Mandailing dengan PMR. Efektifitas modul matematika berbasis budaya Mandailing dengan PMR dilihat dari kemampuan komunikasi matematik pada uji coba II yang menunjukkan hasil bahwa $84,6 \%$ siswa telah memiliki kemampuan komunikasi matematik dengan skor minimal 65 . Hasil ini menunjukkan bahwa modul matematika berbasis budaya Mandailing dengan PMR yang dikembangkan efektif untuk meningkatkan kemampuan komunikasi matematik.

\section{DAFTAR PUSTAKA}

Abdurrahman, M. (2009). Pendidikan bagi anak berkesulitan belajar. Jakarta: Rineka Cipta.

Ahmadi, L. K., dkk. (2011). Strategi pembelajaran berorientasi KTSP. Jakarta: Prestasi Pustakarya.

Akker, J. V. D. (1999). Principles and methods of development research. Dalam Plomp, T; Nieveen, N; Gustafson, K; Branch, R.M; dan Van Den Akker, J (eds). Design Approaches and Tools in Education and Training. London: Kluwer Academic Publisher.

Ansari, B.I, (2009). Komunikasi matematika konsep dan aplikasi. Jakarta: Pena.

Gravemeijer, K, (2010). Developing realistic mathematics education. Utrecht: Freudenthal Institute.

Kilpatrick, J \& Swafford, J. (2002), Helping children learn mathematics. Washington, DC: National Academy Press.

NCTM. (2000). Curriculum and evaluation standard for school mathematics. Reston, VA: NCTM.

Noviani, J., Syahputra, E., \& Murad, A. (2017), The effect of realistic mathematic education (RME) in improving primary school students' spatial ability in subtopic two dimension shape. Journal of Education and Practice, 8(34), 112-126.

Papadakis, S., Kalogiannakis, M., \& Zaranis, N. (2017). Improving mathematics teaching in kindergarten with realistic mathematical education. Early Childhood Educ J, 45(1), 369-378.

Saleh, M. (2012). Pembelajaran kooperatif dengan pendekatan pendidikan matematika realistik (PMR). Jurnal Pendidikan Serambi Ilmu, 13(2), 58-73.

Suprijono, A. (2009). Cooperative learning teori \& aplikasi PAIKEM. Yogyakarta: Pustaka Pelajar.

Suriansyah. (2014). Hubungan budaya sekolah, komunikasi dan komitmen kerja terhadap kinerja guru sekolah dasar negeri. Cakrawala Pendidikan, 1(3), 16-31.

Situs Resmi Pemerintah Kabupaten Mandailing Natal Provinsi Sumatera Utara. Sejarah dan budaya. Diakses tanggal 24 Maret 2020 dari https://madina.go.id/sejarah-dan-budayamandailing-natal/. 
Ade Rahman Matondang: Pengembangan Modul Matematika Berbasis Budaya Mandailing dengan Pendekatan Matematika Realistik (PMR) untuk Meningkatkan Kemampuan Komunikasi Matematik

Tati. (2009). Pengembangan perangkat pembelajaran berbasis konstekstual pokok bahasan turunan di Madrasah Aliyah Negeri 3 Palembang. Jurnal Pendidikan Matematika, 3 (1), 75-89.

Thiagarajan, S., Semmel,D.S., \& Semmel,M.I. (1974). Instructional development for training teachers of expectional children Minneapolis. Minnesota: Leadership Training Institute/Special Education, University of Minnesota. 